\title{
Synthesis, structure, thermal decomposition and spectral properties of neutral $\left[\mathrm{Fe}(\boldsymbol{b p t a})_{2}(\mathrm{etOH})_{2}(\mathrm{NCS})_{2}\right]$
}

\author{
Zuzana Lukačovičováa , Róbert Uhreckýa , Ján Moncola ${ }^{a}$, Darina Lackováa, \\ Iveta Ondrejkovičováa, Marian Komana ${ }^{a}$, Zuzana Mičicováb ${ }^{b}$ Zuzana Harmatováb \\ ${ }^{a}$ Institute of Inorganic Chemistry, Technology and Materials, Slovak University of Technology, \\ Radlinského 9, SK - 81237 Bratislava, Slovakia \\ ${ }^{b}$ Faculty of Industrial Technologies in Púchov, University of Alexander Dubček in Trenčin, \\ I. Krasku 491/30, 02001 Púchov, Slovakia \\ xfaberovaz@stuba.sk
}

\begin{abstract}
The new iron(II) complex $\left[\mathrm{Fe}(b p t a)_{2}(\mathrm{EtOH})_{2}(\mathrm{NCS})_{2}\right] \quad($ bpta $=$ 3,3'-(1,2,4-thiadiazole-3,5-diyl $)$ dipyridine; $\mathrm{EtOH}=$ ethanol) has been prepared by refluxing $\mathrm{Fe}(\mathrm{NCS})_{3}$ or $\mathrm{Fe}(\mathrm{NCS})_{2}$ with thionicotinamide in an ethanol solution and characterized by elemental analysis, infrared spectroscopy, thermal decomposition and X-ray structural analysis. The characterized compound is a mixture of three regioisomers resulting from differential coordination by the 3- and 5-position 2-pyridyl groups. The bpta ligand was generated in situ by the oxidation dimerization of thionicotinamide. X-ray single-crystal diffraction revealed that the crystal structure is centrosymmetric and the complex crystallizes in the triclinic space group $P$ - 1 . The iron(II) atom lies in the centre of symmetry and it is octahedrally coordinated by two nitrogen atoms from two thiocyanate anions and two oxygen atoms from ethanol molecules in the equatorial plane and two nitrogen atoms of pyridine rings from two bpta ligands in the axial positions. This complex represents the second example of metal complex with bpta.
\end{abstract}

Keywords: 3,3'-(1,2,4-Thiadiazole-3,5-diyl)dipyridine - Thiocyanate complex - Iron(II) complex - Crystal structure

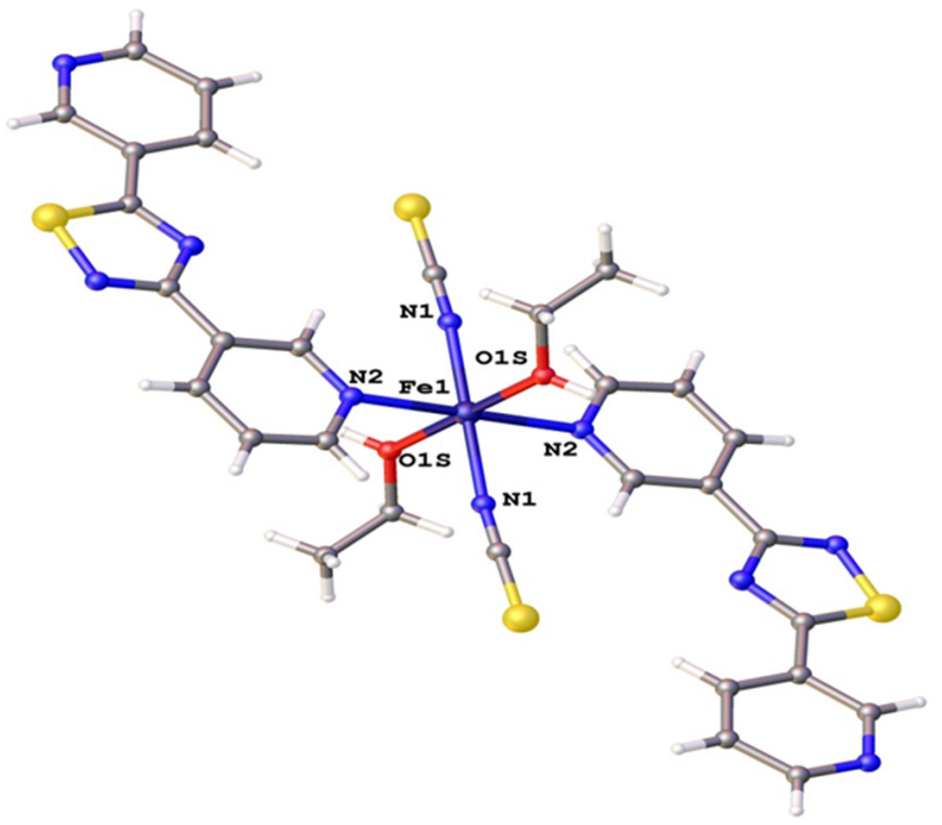

\section{Introduction}

Compounds containing a thiadiazole moiety possess interesting biological activity due to the strong aromaticity of this ring system (Siddiqui et. al., 2009; Semwal et al., 2013). In recent years, thiadiazoles and their metal complexes have been extensively studied because of their potential applications in pharmaceutical, agriculture, industrial, polymer and coordination chemistry (Richardson et al., 2002; Leung-Toung et al., 2003; Bentiss et al., 2004; Niu et al., 2008; Boeini, 2009; Klingele et al., 2010; Bhuvaa et al., 2011; Klingele et al., 2012; Liu et al., 2012).

Thiadiazoles with two substituted pyridyl groups, i.e. $\mathrm{N}, \mathrm{N}^{\prime}$-(thiadiazole-diyl)dipyridine $\left(\mathrm{N}=\mathrm{N}^{\prime}=2,3\right.$ or 4 ), occur in 12 different isomeric forms such as $\mathrm{N}, \mathrm{N}^{\prime}$ (1,2,3-thiadiazole-4,5-diyl)dipyridine, $\quad \mathrm{N}, \mathrm{N}^{\prime}-(1,2,4-$ 
thiadiazole-3,5-diyl)dipyridine, N,N'-(1,3,4-thiadiazole-2,5-diyl)dipyridine and N,N'-(1,2,5-thiadiazole3,4-diyl)dipyridine. In literature, almost all information concerning N,N'-(1,3,4-thiadiazole-2,5-diyl)dipyridine and its coordination compounds (84 examples) (Allen, 2002) two complexes with 2,2'-(1,2,5thiadiazole-3,4-diyl)dipyridine (Richardson et al., 2002) and one complex with 3,3'-(1,2,4-thiadiazole3,5-diyl)dipyridine (Uhrecký et al., 2014) can be found. In addition, six crystal structures of $\mathrm{N}$-[5(pyridine-N-yl)-1,2,4-thiadiazole-3-yl)]pyridinium salts are known; two with 4-[5-(pyridine-4-yl)-1,2,4thiadiazole-3-yl)]pyridinium and four with 3-[5(pyridine-3-yl)-1,2,4-thiadiazole-3-yl)]pyridinium (Aragoni et al., 2012). Thiadiazoles have four potential donor sites, viz. two $\mathrm{N}$ atoms of the pyridine rings and two $\mathrm{N}$ atoms of the thiadiazole ring. Only seven iron complexes with other isomers such as 2,2'-(1,3,4thiadiazole-2,5-diyl)dipyridine and 2,2'-(1,2,5-thiadiazole-3,4-diyl)dipyridine which are coordinated to the $\mathrm{Fe}(\mathrm{II})$ atom forming five membered chelate rings [4-6]. Only one example with monodentate N,N'(1,2,4-thiadiazole-3,5-diyl)dipyridine (the first complex contains coordinated methanol molecules instead ethanol) has been presented (Uhrecký et al., 2014).

This paper is a continuation of our previously reported studies on iron complexes with pyridine derivatives (Ondrejkovičová et al., 2008; Štefániková et al., 2008; Ondrejkovičová et al., 2009; Fargašová et al., 2010). The synthesis, crystal and molecular structure and properties of an Fe(II) complex, $\left[\mathrm{Fe}(b p t a)_{2}(\mathrm{EtOH})_{2}(\mathrm{NCS})_{2}\right]$ where $b p t a$ is 3,3 '-(1,2,4thiadiazole-3,5-diyl)dipyridine and $\mathrm{EtOH}$ is ethanol, are reported on.

\section{Experimental}

\section{Materials and physical measurements}

All chemicals were purchased commercially and used without further purification. A $96 \%$ vol. ethanol was used as the solvent. Elemental analyses (C, H, N and S) were accomplished by means of a Flash EA 1112 analyzer. The presence of gaseous hydrogen sulfide, released during the reaction, was proven with $\mathrm{Pb}\left(\mathrm{NO}_{3}\right)_{2}$. Infrared spectra $\left(4000-100 \mathrm{~cm}^{-1}\right)$ were measured in solid state using the $\mathrm{KBr}$ technique and recorded on a Nicolet 5700 FTIR spectrophotometer. The thermal decomposition study was carried out on a Derivatographe MOM Budapest instrument in air atmosphere using a ceramic crucible with the sample mass of $150 \mathrm{mg}$ from room temperature up to $1000{ }^{\circ} \mathrm{C}$. The rate of temperature increase of $10^{\circ} \mathrm{C} \mathrm{min}^{-1}$ was chosen for the measurement.

\section{Synthesis of $\left[\mathrm{Fe}(\mathrm{bpta})_{2}(\mathrm{EtOH})_{2}(\mathrm{NCS})_{2}\right]$}

A solution of $\mathrm{Fe}(\mathrm{NCS})_{3}$ prepared from KSCN $(0.145 \mathrm{~g}, 1.5 \mathrm{mmol})$ and $\mathrm{FeCl}_{3} \cdot 6 \mathrm{H}_{2} \mathrm{O}(0.135 \mathrm{~g}$, $0.5 \mathrm{mmol})$ in EtOH $(25 \mathrm{~mL})$ was added to a solution of thionicotinamide $(0.276 \mathrm{~g}, 2.0 \mathrm{mmol})$ in $\mathrm{EtOH}$ $(25 \mathrm{~mL})$ under continuous stirring. The reaction mixture was refluxed for $2 \mathrm{~h}$. The insoluble $\mathrm{KCl}$ formed during the reaction was filtered out after cooling. The dark red filtrate was allowed to stand at room temperature for seven days. The resulting well-formed orange crystals of the title compound were suitable for X-ray structure analysis. Anal. Calc. for $\mathrm{C}_{30} \mathrm{H}_{28} \mathrm{~N}_{10} \mathrm{O}_{2} \mathrm{~S}_{4} \mathrm{Fe}: \mathrm{C}, 48.38 ; \mathrm{H}, 3.79 ; \mathrm{N}, 18.81 ; \mathrm{S}$, 17.22. Found: C, 48.19; H, 3.82; N, 19.02; S, 17.18 . The same compound was similarly prepared from $\mathrm{FeCl}_{2} \cdot 4 \mathrm{H}_{2} \mathrm{O}$, KSCN and thionicotinamide in the molar ratio of 1:2:4. Found for $\mathrm{C}_{30} \mathrm{H}_{28} \mathrm{~N}_{10} \mathrm{O}_{2} \mathrm{~S}_{4} \mathrm{Fe}$ prepared from $\mathrm{FeCl}_{2} \cdot 4 \mathrm{H}_{2} \mathrm{O}: \mathrm{C}, 48.22 ; \mathrm{H}, 3.47 ; \mathrm{N}$, 19.12; S, 17.54 .

\section{X-ray crystallographic data collection and refinement} Intensity data for $\left[\mathrm{Fe}(b p t a)_{2}(\mathrm{EtOH})_{2}(\mathrm{NCS})_{2}\right]$ were obtained on a Bruker-Nonius KappaCCD diffractometer with graphite-monochromated Mo $\mathrm{K \alpha}$ radiation $(\lambda=0.71073 \AA)$ at $150 \mathrm{~K}$ using an Oxford Cryostream low-temperature device. Absorption correction was applied using the program SADABS (Sheldrick, 2003). Data reduction was performed employing EvalCCD (Duisenberg et al., 2003). The structure was solved by direct methods using the program SIR-2011 (Burla et al., 2012) and refined by the full-matrix least-squares method on all $F^{2}$ data using the program SHELXL-2013 (Sheldrick, 2015). Geometrical analysis was performed using SHELXL-2013. The structure was drawn by OLEX2 (Dolomanov et al., 2009) and MERCURY (Macrae et al., 2006) softwares. The single crystal suite WINGX was used as an integrated system for all crystallographic programs and software when preparing the material for publication (Farrugia, 2012).

All non-hydrogen atoms of the title compound were refined anisotropically as independent atoms. Hydrogen atoms were mostly localized on a difference Fourier map; however, to ensure uniformity of the crystal treatment, all hydrogen atoms were recalculated into idealized positions and assigned temperature factors $U_{\text {iso }}(\mathrm{H})=1.2 U$ eq for aromatic and methylene carbon atoms or of 1.5 Ueq for the methyl group and $\mathrm{O}-\mathrm{H}$ group with $d(\mathrm{C}-\mathrm{H})=0.95 \AA$ for hydrogen atoms in aromatic rings, $d(\mathrm{C}-\mathrm{H})=0.98$ and $0.99 \AA$ for hydrogen atoms in the ethyl group $\left(-\mathrm{CH}_{2}-\right.$ and $-\mathrm{CH}_{3}$, respectively); and $d(\mathrm{O}-\mathrm{H})=0.82 \AA$ for hydrogen atoms in the hydroxyl group. Crystal data and conditions of data collection and refinement are 
reported in Table 1, bond lengths and bond angles are reported in Table 2, and hydrogen bond parameters are reported in Table 3. Discrete positional disorder of the thiadiazole ring [C9A, C10A, N3A, N4A, S2A] and [C9B, C10B, N3B, N4B, S2B] was observed in the title compound with site occupancy factors of 0.84 and 0.16 . Both disordered groups were restrained using SADI and EADP commands in the SHELXL-2013 program.

Tab. 1. Crystal data, X-ray measurements and structure determination summary for $\left[\mathrm{Fe}(b p t a)_{2}(\mathrm{EtOH})_{2}(\mathrm{NCS})_{2}\right]$.

\begin{tabular}{|c|c|}
\hline Chemical formula & $\mathrm{C}_{30} \mathrm{H}_{28} \mathrm{FeN}_{10} \mathrm{OS}_{4}$ \\
\hline Formula weight & 744.72 \\
\hline Temperature (K) & 150 \\
\hline Crystal color, habit & Orange, needle \\
\hline Crystal system, space group & Triclinic, $P-1$ \\
\hline$a(\AA)$ & $7.413(2)$ \\
\hline$b(\AA)$ & $9.157(2)$ \\
\hline$c(\AA)$ & $12.804(3)$ \\
\hline$\alpha\left(^{\circ}\right)$ & $80.61(3)$ \\
\hline$\beta\left(^{\circ}\right)$ & $77.69(3)$ \\
\hline$\gamma\left({ }^{\circ}\right)$ & $81.42(3)$ \\
\hline$V\left(\AA^{3}\right)$ & $831.8(3)$ \\
\hline$Z$ & 2 \\
\hline$D_{\text {calc }}\left(\right.$ g.cm $\mathrm{cm}^{-3)}$ & 1.487 \\
\hline Radiation type & Mo $K \alpha$ \\
\hline$\alpha\left(\mathrm{mm}^{-1}\right)$ & 0.75 \\
\hline Crystal size (mm) & $0.23 \times 0.23 \times 0.17$ \\
\hline Diffractometer & Bruker-Nonius KappaCCD \\
\hline Abs. correction & Multi-scan $S A D A B S$ \\
\hline$T_{\min }, T_{\max }$ & $0.842,0.880$ \\
\hline$S$ & 1.068 \\
\hline$R_{\text {int }}$ & 0.040 \\
\hline$R_{1}\left[F^{2}>2 \sigma\left(F^{2}\right)\right], w R_{2}\left(F^{2}\right)$ & $0.0306,0.0699$ \\
\hline No. of reflections & 3337 \\
\hline No. of parameters & 234 \\
\hline No. of restraints & 19 \\
\hline$\left.\Delta\rangle_{\max }, \Delta\right\rangle_{\min }\left(\mathrm{e} \AA^{-3}\right)$ & $0.47,-0.46$ \\
\hline CCDC no. & 889109 \\
\hline
\end{tabular}

Tab. 2. Selected geometric parameters $\left(\AA,^{\circ}\right)$ for $\left[\mathrm{Fe}(b p t a)_{2}(\mathrm{EtOH})_{2}(\mathrm{NCS})_{2}\right]$.

\begin{tabular}{llll}
\hline Bonds & & & \\
$\mathrm{Fe} 1-\mathrm{N} 1$ & $2.107(2)$ & $\mathrm{Fe} 1-\mathrm{N} 2$ & $2.271(2)$ \\
$\mathrm{Fe} 1-\mathrm{O} 1 \mathrm{~S}$ & $2.108(1)$ & & \\
Angles & & & \\
$\mathrm{N} 1-\mathrm{Fe} 1-\mathrm{N} 2^{\mathrm{i}}$ & $88.97(6)$ & $\mathrm{N} 2-\mathrm{Fe} 1-\mathrm{O} 1 \mathrm{~S}^{\mathrm{i}}$ & $88.29(6)$ \\
$\mathrm{N} 1-\mathrm{Fe} 1-\mathrm{N} 2$ & $91.03(6)$ & $\mathrm{N} 2-\mathrm{Fe} 1-\mathrm{O} 1 \mathrm{~S}$ & $91.71(6)$ \\
$\mathrm{N} 1-\mathrm{Fe} 1-\mathrm{O} 1 \mathrm{~S}^{\mathrm{i}}$ & $91.90(6)$ & $\mathrm{N} 1-\mathrm{Fe} 1-\mathrm{O} 1 \mathrm{~S}$ & $88.10(6)$ \\
\hline
\end{tabular}

Symmetry code: (i) $-x+1,-y,-z+1$.

\section{Results and discussion}

\section{Synthesis and structure}

$\left[\mathrm{Fe}(\text { bpta })_{2}(\mathrm{EtOH})_{2}(\mathrm{NCS})_{2}\right]$ was prepared by refluxing the reaction mixtures containing thionicotinamide (tnia), KSCN and $\mathrm{FeCl}_{3}$ or $\mathrm{FeCl}_{2}$ in an $\mathrm{EtOH}$ solution (Scheme 1). It is believed that the bpta ligand is generated in situ by the oxidation dimerization of thionicotinamide (Scheme 2). The formed product is a mixture of three regioisomers resulting from differential coordination by the 3- and 5-position 2-pyridyl groups (Scheme 3). In case of Fe(NCS $)_{3}$ as the starting compound, the iron(III) atom was reduced to iron(II) at first and then formed bpta molecules coordinated to the Fe atom. Released gaseous hydrogen sulfide was detected by smell and also by a reaction with $\mathrm{Pb}\left(\mathrm{NO}_{3}\right)_{2}$. An excess of tnia with respect to the reaction stoichiometry reaction remained unreacted (Scheme 1).

Generally, oxidation dimerization of thioamides is a method for the preparation of 3,5-disubstituted 1,2,4-thiadiazoles (Takikawa et al., 1985; Boeini, 2009; Patil et al., 2009).

The centrosymmetric complex $\left[\mathrm{Fe}(b p t a)_{2}(\mathrm{EtOH})_{2}\right.$ $\left.(\mathrm{NCS})_{2}\right]$ crystallizes in the triclinic system with the space group $P-1$. Molecular structure of the main part of the neutral mononuclear complex disorder is displayed in Fig. 1. The other two parts of disorders are drawn in Fig. 2.

The iron(II) atom lies in the centre of symmetry. It is octahedrally coordinated by two nitrogen atoms from two thiocyanate anions and two oxygen atoms from ethanol molecules in the equatorial plane and two nitrogen atoms of pyridine rings from two bpta

Tab. 3. Selected hydrogen bond parameters for $\left[\mathrm{Fe}(b p t a)_{2}(\mathrm{EtOH})_{2}(\mathrm{NCS})_{2}\right]$.

\begin{tabular}{lcccc}
\hline$D-\mathrm{H} \cdots A$ & $D-\mathrm{H}(\AA)$ & $\mathrm{H} \cdots A(\AA)$ & $D \cdots A(\AA)$ & $\mathrm{D}-\mathrm{H} \cdots A\left(^{\circ}\right)$ \\
\hline $\mathrm{O} 1 \mathrm{~S}-\mathrm{H} 1 \mathrm{~S} \cdots \mathrm{N} 5^{\mathrm{ii}}$ & 0.82 & 1.91 & $2.727(2)$ & 178 \\
\hline
\end{tabular}

Symmetry code: (ii) $x-1, y, z+1$. 


$$
\mathrm{FeCl}_{2}+2 \mathrm{KSCN}+4 \text { tnia } \stackrel{\mathrm{EtOH}}{\longrightarrow}\left[\mathrm{Fe}(b p t a)_{2}(\mathrm{EtOH})_{2}(\mathrm{NCS})_{2}\right]+2 \mathrm{H}_{2} \mathrm{~S}+2 \mathrm{KCl}
$$

Scheme 1. Preparation of $\left[\mathrm{Fe}(b p t a)_{2}(\mathrm{EtOH})_{2}(\mathrm{NCS})_{2}\right]$.<smiles>NC(=S)c1cccnc1</smiles>

Scheme 2. Formation of bpta by oxidation dimerization of thionicotinamide.<smiles>c1cncc(-c2nsc(-c3cccnc3)n2)c1</smiles>

<smiles></smiles>

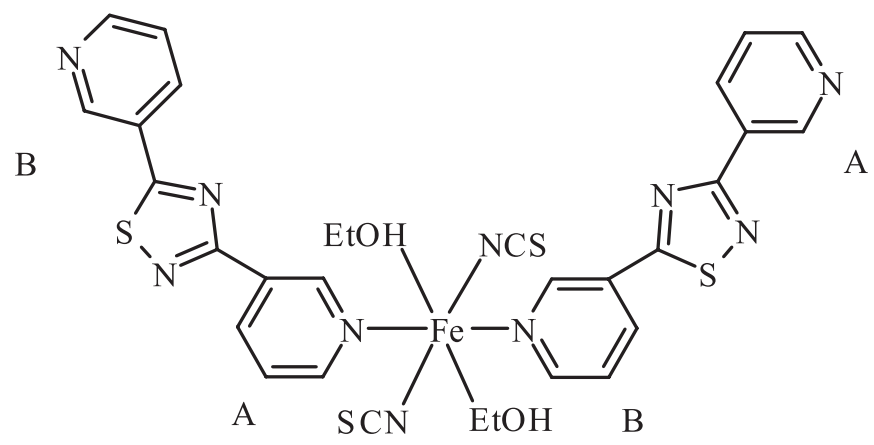

Scheme 3. Regioisomers of $\left[\mathrm{Fe}(b p t a)_{2}(\mathrm{EtOH})_{2}(\mathrm{NCS})_{2}\right]$.

ligands in the axial positions. The data indicate that all $\mathrm{Fe}-\mathrm{N}$ and $\mathrm{Fe}-\mathrm{O}$ distances are in the range of 2.107(2)-2.271(2) A, typical for high-spin iron(II) compounds. However, $\mathrm{Fe}-\mathrm{N}(b p t a)$ distances are longer than the $\mathrm{Fe}-\mathrm{N}(\mathrm{NCS})$ and $\mathrm{Fe}-\mathrm{O}(\mathrm{EtOH})$ ones, where $\mathrm{Fe}-\mathrm{N}(\mathrm{NCS})=2.107(2) \AA$ and $\mathrm{Fe}-$ $\mathrm{O}(\mathrm{EtOH})=2.108(1) \AA ; \mathrm{Fe}-\mathrm{N}(b p t a)=2.271(2) \AA$. These bond distances are comparable with those reported for $\left[\mathrm{Fe}(t p a)(\mathrm{NCS})_{2}\right](t p a=$ tris $($ pyridin-2-yl $)$ amine) (Vei et al., 2011), $\left[\mathrm{Fe}(\mathrm{NCS})_{4}(\mathbf{1})_{5}\right](\mathbf{1}=4$ phenylamino-1,2,4-triazole) (Roubeau et al., 2013) and
$\left[\mathrm{Fe}(\mathrm{NCS})_{2}(3-b p o)_{2}\left(\mathrm{H}_{2} \mathrm{O}\right)_{2}\right](3-b p o=2,5$-di-3-pyridyl1,3,4-oxadiazole) (Zhao et al., 2005). Thiocyanate anions, bpta and EtOH molecules are coordinated to iron(II) in a monodentate terminal mode in mutual trans-positions.

In the title complex, the uncoordinated nitrogen atom of the pyridine ring from the bpta ligand and the hydrogen atom from the ethanol molecule are joined by an O1S-H1S...N5 hydrogen bond (Table 3) into a 1D polymeric chain (Fig. 3). Moreover, the thiadiazole rings of the bpta ligands $[\mathrm{N} 3, \mathrm{~N} 4$, 
C9, C10, S2] are involved in face-to-face aromatic $\pi-\pi$ stacking interactions with the centroid to centroid distance of $3.627 \AA$ (Fig. 4a). These 1D chains are stacked in parallel to form $2 \mathrm{D}$ sheet through the inter-chain aromatic interaction between the thiadiazole rings. The hydrogen bonds and $\pi-\pi$ stacking interactions play a significant role in the expansionding of the mononuclear units to the 2D supramolecular network in the complex (Fig. 4b).

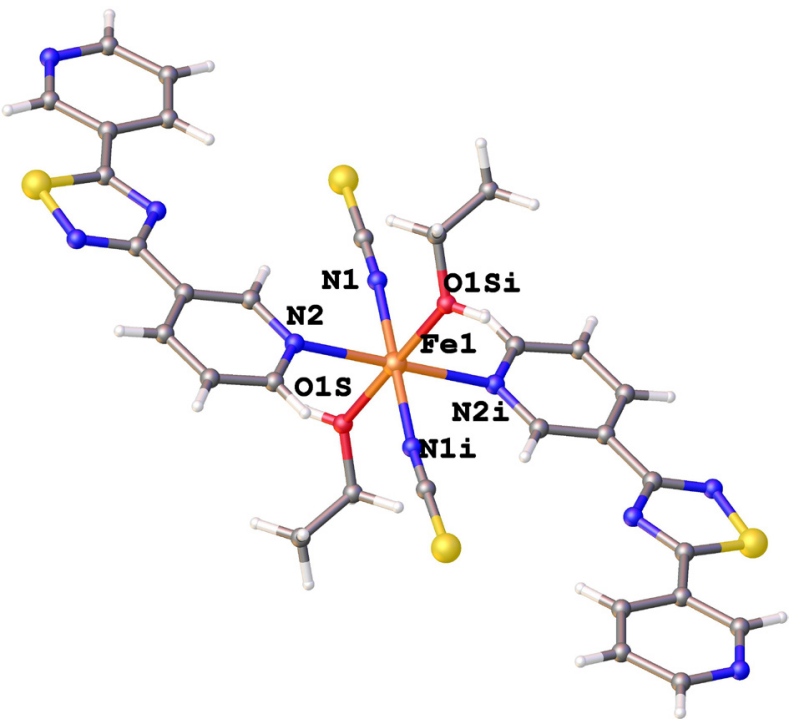

Fig. 1. Molecular structure of $\left[\mathrm{Fe}(b p t a)_{2}(\mathrm{EtOH})_{2}(\mathrm{NCS})_{2}\right]$. Symmetry code: (i) $-x+1,-y,-z+1$.
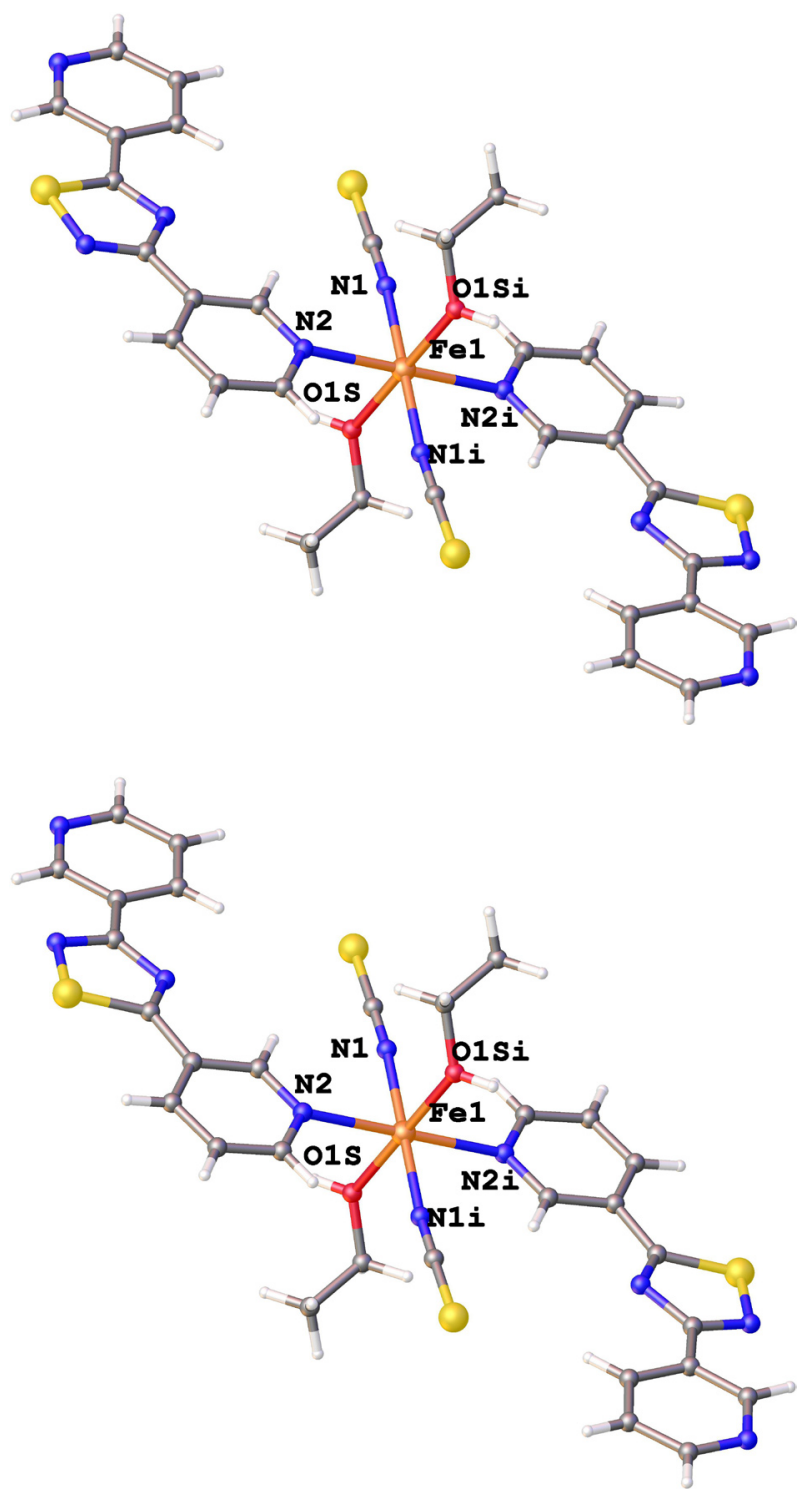

Fig. 2. Molecular structure of the other two isomers of $\left[\mathrm{Fe}(b p t a)_{2}(\mathrm{EtOH})_{2}(\mathrm{NCS})_{2}\right]$. Symmetry code: (i) $-x+1,-y,-z+1$.

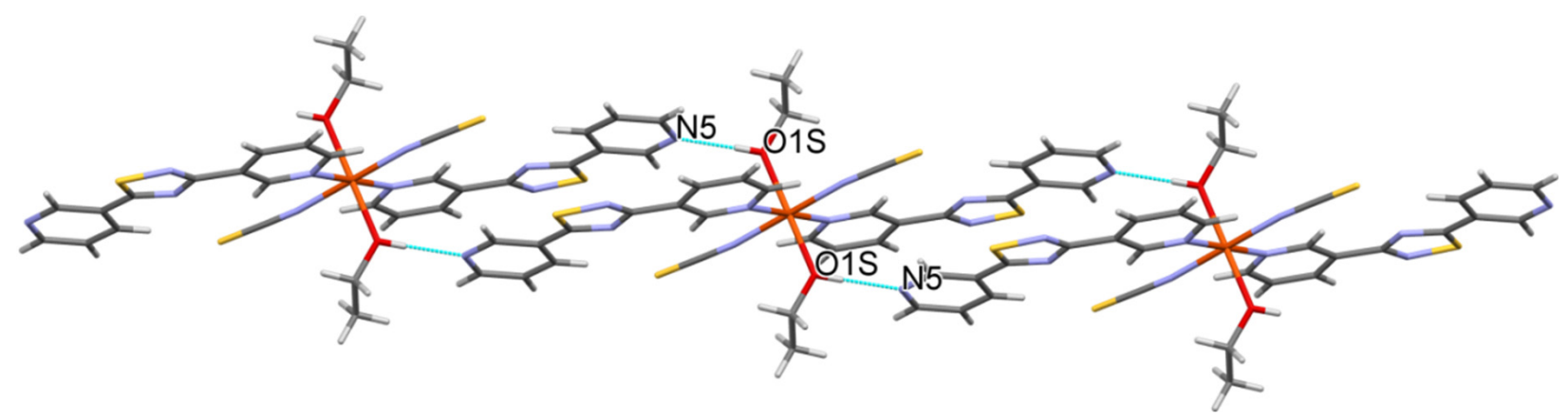

Fig. 3. View of the $1 \mathrm{D}$ chain of $\left[\mathrm{Fe}(b p t a)_{2}(\mathrm{EtOH})_{2}(\mathrm{NCS})_{2}\right]$ formed by $\mathrm{O}-\mathrm{H} \cdots \mathrm{N}$ hydrogen bonds. 




a)

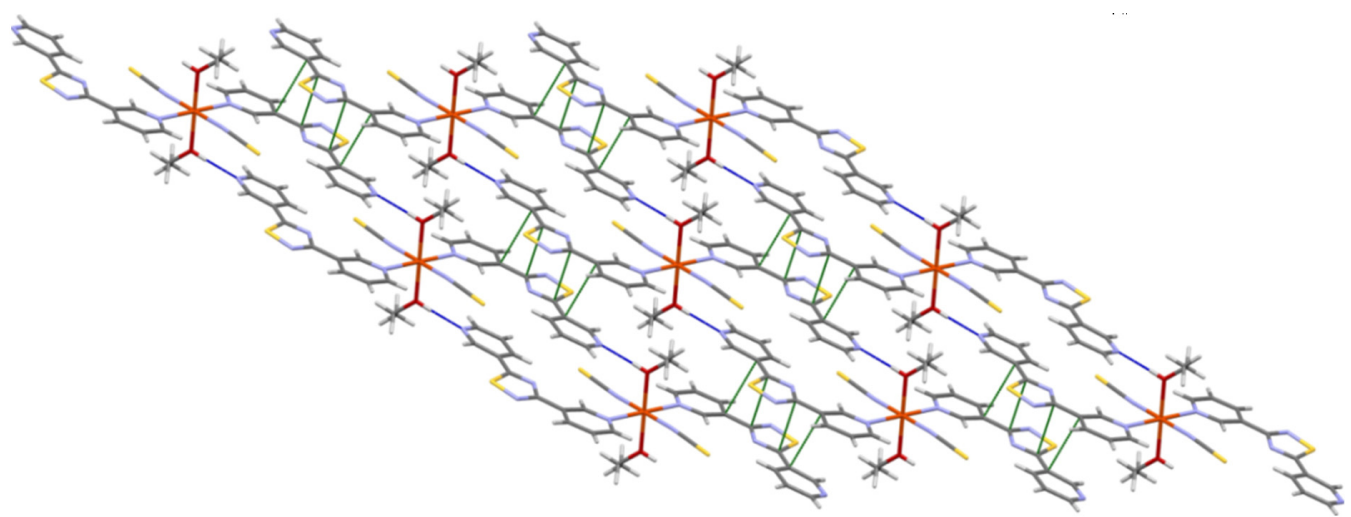

b)

Fig. 4. Schematic representation of $\pi-\pi$ stacking interactions in $\left[\mathrm{Fe}(b p t a)_{2}(\mathrm{EtOH})_{2}(\mathrm{NCS})_{2}\right](\mathbf{a})$ and packing diagram along the $\mathrm{b}$ axis in $\left[\mathrm{Fe}(b p t a)_{2}(\mathrm{EtOH})_{2}(\mathrm{NCS})_{2}\right]$ showing the 2D supramolecular network (b).

\section{IR spectra}

Infrared spectra of the title compound prepared by two methods are practically identical. They show characteristic bands of bpta $\left(\nu_{\max } / \mathrm{cm}^{-1}: 1598(\mathrm{~s})\right.$, 1579(sh), 1478(m), 1393(s), 1338(s), 1302(m), $1042(\mathrm{~s})$ and $731(\mathrm{~s}))$, which are very close to the published data for free bpta (Uhrecký et al., 2014). The spectra show typical bands for N-bond thiocyanate complexes (Zhao et al., 2005; Ondrejkovičová et al., 2008). It was assumed that the $\mathrm{C}-\mathrm{N}$ stretch in the Fe-NCS complexes lies at $2075(\mathrm{~s}) \mathrm{cm}^{-1}$, the $\mathrm{C}-\mathrm{S}$ stretch at $809(\mathrm{~m}) \mathrm{cm}^{-1}$ and the NCS bend at $475(\mathrm{w}) \mathrm{cm}^{-1}$. The presence of ethanol molecules in the complex is indicated by bands at $1097(\mathrm{w})$ and $1045(\mathrm{~m}) \mathrm{cm}^{-1}(\nu(\mathrm{C}-\mathrm{O})), 2801(\mathrm{w}) \mathrm{cm}^{-1}(\nu(\mathrm{O}-\mathrm{H}))$, $2722(\mathrm{~m}) \quad \mathrm{cm}^{-1}(\nu(\mathrm{C}-\mathrm{H})), \quad 1457(\mathrm{~m}) \quad \mathrm{cm}^{-1}\left(\nu\left(\mathrm{CH}_{3}\right)\right)$ and $1473(\mathrm{~m}) \mathrm{cm}^{-1}\left(\nu\left(\mathrm{CH}_{2}\right)\right)$ (Patil et al., 2009). In the far infrared area, important stretches were observed: the band at $292(\mathrm{~m}) \mathrm{cm}^{-1}$ can be assigned to $\nu(\mathrm{Fe}-\mathrm{N})$ of the $\mathrm{N}$-bond NCS group and the band at $253(\mathrm{w}) \mathrm{cm}^{-1}$ indicates that the bpta ligand is bond to the iron atom through the nitrogen atom of pyridine ring. The band assigned to $\nu(\mathrm{Fe}-\mathrm{O})$ occurred at $407(\mathrm{~m}) \mathrm{cm}^{-1}$ (Ondrejkovičová et al., 2008; Štefániková et al., 2008; Nakamoto, 2009).

\section{Thermal decomposition}

TG and DTA curves of the decomposition of the title compound are shown in Fig. 5. The TG curve of this complex indicates that it is stable up to $150{ }^{\circ} \mathrm{C}$, when the slow decomposition to $\mathrm{Fe}_{2} \mathrm{O}_{3}$ starts, as to the final product formed at $550{ }^{\circ} \mathrm{C}$ (Table 4 ). The first step, between 150 and $300^{\circ} \mathrm{C}$, is accompanied by a $12.40 \%$ mass loss, in the release of two molecules of ethanol. The second step took place between 300 and $550{ }^{\circ} \mathrm{C}$ and is accompanied by a $64.56 \%$ mass loss. It is attributed to the decomposition of two molecules of bpta. The third step, above $550^{\circ} \mathrm{C}$,

$$
\begin{gathered}
{\left[\mathrm{Fe}(\text { bpta })_{2}(\mathrm{EtOH})_{2}(\mathrm{NCS})_{2}\right] \stackrel{150-300{ }^{\circ} \mathrm{C}}{\longrightarrow}\left[\mathrm{Fe}(\text { bpta })_{2}(\mathrm{NCS})_{2}\right]+2 \mathrm{EtOH}} \\
{\left[\mathrm{Fe}(\text { bpta })_{2}(\mathrm{NCS})_{2}\right] \stackrel{300-550{ }^{\circ} \mathrm{C}}{\longrightarrow} \text { “Fe } \cdot 2 \mathrm{NCS} \text { " }+2 \text { bpta }} \\
\text { "4 Fe } \cdot \mathrm{NCS"}+11 \mathrm{O}_{2} \stackrel{550-1000{ }^{\circ} \mathrm{C}}{\longrightarrow} 2 \mathrm{Fe}_{2} \mathrm{O}_{3}+4 \mathrm{SO}_{2}+4 \mathrm{CO}_{2}+2 \mathrm{~N}_{2}
\end{gathered}
$$

Scheme 4. Thermal decomposition of $\left[\mathrm{Fe}(b p t a)_{2}(\mathrm{EtOH})_{2}(\mathrm{NCS})_{2}\right]$. 


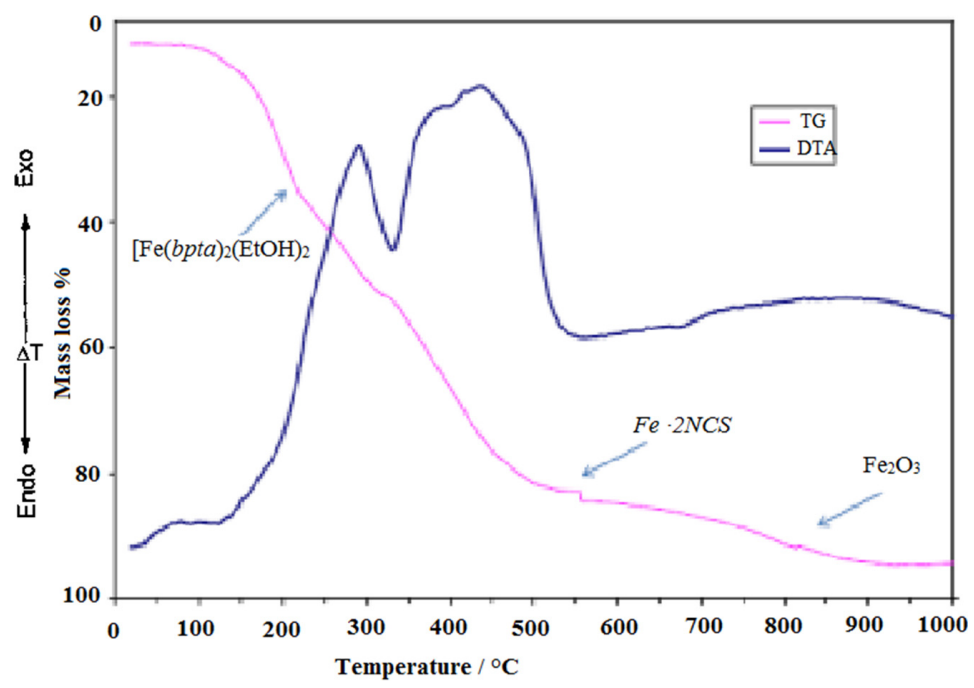

Fig. 5. TG and DTA curves of $\left[\mathrm{Fe}(b p t a)_{2}(\mathrm{EtOH})_{2}(\mathrm{NCS})_{2}\right]$.

Sample weight: $150 \mathrm{mg}$; atmosphere: static air; heating rate: $10^{\circ} \mathrm{C} \mathrm{min}^{-1}$.

Tab. 4. Thermal decomposition data.

\begin{tabular}{|c|c|c|c|c|c|}
\hline \multicolumn{6}{|c|}{$\left[\mathrm{Fe}(\text { bpta })_{2}(\mathrm{EtOH})_{2}(\mathrm{NCS})_{2}\right]$} \\
\hline \multirow{2}{*}{$\begin{array}{l}T_{\text {peaks }} \\
{\left[{ }^{\circ} \mathrm{C}\right]}\end{array}$} & \multirow{2}{*}{$\begin{array}{l}T_{\text {range }} \\
{[\stackrel{\circ}{ } \mathrm{C}]}\end{array}$} & \multicolumn{2}{|c|}{ Mass loss/\% } & \multirow{2}{*}{$\begin{array}{c}\text { Intermediate } \\
\text { decomposition }\end{array}$} & \multirow{2}{*}{$\begin{array}{r}\text { Final } \\
\text { produc }\end{array}$} \\
\hline & & Found & Calc. & & \\
\hline 198 & $150-300$ & 12.40 & 12.38 & $\mathrm{Fe}(b p t a)_{2}(\mathrm{NCS})_{2}$ & \\
\hline 462 & $300-550$ & 64.56 & 64.53 & $" \mathrm{Fe} \cdot 2 \mathrm{NCS} "$ & $\mathrm{Fe}_{2} \mathrm{O}_{3}$ \\
\hline 872 & $500-1000$ & 15.36 & 15.60 & "2NCS" & \\
\hline
\end{tabular}

is accompanied by a $15.36 \%$ mass loss. During this step, $\mathrm{Fe}_{2} \mathrm{O}_{3}$ is formed as the final product of thermal decomposition. We assume that gaseous products: $\mathrm{SO}_{2}, \mathrm{CO}_{2}$ and $\mathrm{N}_{2}$, are released similarly as in the case of the CuSCN and AgSCN decomposition (Ptaszyński et al., 1998). The most probable thermal decomposition scheme is as follows:

\section{Conclusions}

In summary, a new iron(II) complex, $\left[\mathrm{Fe}(b p t a)_{2}\right.$ $\left.(\mathrm{EtOH})_{2}(\mathrm{NCS})_{2}\right]$, was prepared by the reaction of $\mathrm{Fe}(\mathrm{NCS})_{3}$ or $\mathrm{Fe}(\mathrm{NCS})_{2}$ with thionicotinamide in ethanol. The bpta ligand was generated in situ by the oxidation dimerization of thionicotinamide. This complex represents the second example of a metal complex with N,N'-(1,2,4-thiadiazole-3,5-diyl)dipyridine. The characterized compound is a mixture of three regioisomers resulting from differential coordination by the 3- and 5-position 2-pyridyl groups. $\mathrm{X}$-ray diffraction analysis of the title complex showed that the system of the $\mathrm{N}-\mathrm{H} \cdots \mathrm{O}$ hydrogen bonds and $\pi-\pi$ stacking interactions stabilize the crystal lattice to a 2D supramolecular network. Its molecular structure is in good agreement with the observed infrared spectra and also with the data from literature. Thermal decomposition of the compound was initiated by the elimination of ethanol. The results revealed that $\mathrm{Fe}_{2} \mathrm{O}_{3}$ remains as a residue at the end of the thermal degradation process.

\section{Acknowledgements}

This work was supported by the Slovak Grant Agency (VEGA 1/0056/13 and APVV-0014-11).

This article was created with the support of the Ministry of Education, Science, Research and Sport of the Slovak Republic within the Research and Development Operational Programme for the project "University Science Park of STU Bratislava”, ITMS 26240220084, co-funded by the European Regional Development Fund.

\section{References}

Allen FH (2002) Acta Cryst B58: 380-388.

Aragoni C, Garau A, Isaia F, Lippolis V, Montis R, Pintus A (2012) CrystEngComm 14: 5809-5823.

Bentiss F, Lebrini M, Vezin H, Lagrenée M (2004) Mat Chem Phys 87: 18-23.

Bhuvaa H, Sahua D, Shaha B, Modia DC, Patel MB (2011) Pharmacologyonline 1: 528-543. 
Boeini HZ (2009) J Iran Chem Soc 6: 547-551.

Burla MC, Caliandro R, Camalli M, Carrozzini B, Cascarano GL, Giacovazzo C, Mallamo M, Mazzone A, Polidori G, Spagna R (2012) J Appl Crystallogr 45: 357-361.

Dolomanov OV, Bourhis LJ, Gildea RJ, Howard JAK, Puschmann H (2009) J Appl Crystallogr 42: 339-341.

Duisenberg AJM, Kroon-Batenburg LMJ, Schreurs AMM (2003) J Appl Crystallogr 36: 220-229.

Fargašová A, Ondrejkovičová I, Kramarová Z, Fáberová Z (2010) Bioresource Technology 101: 6410-6415.

Farrugia LJ (2012) J Appl Crystallogr 45: 849-854.

Klingele J, Kaase D, Hilgert J, Steinfeld G, Klingele MH, Lach (2010) J Chem Soc Dalton Trans 39(19): 495-507.

Klingele J, Kaase D, Klingele MH, Lach J (2012) J. Chem Soc Dalton Trans 41: 1397-1406.

Leung-Toung R, Wodzinska J, Li W, Lowrie J, Kukreja R, Desilets D, Karimian K, Tam TF (2003) Bioorg Med Chem 11: 5529-5537.

Liu JQ, Wang YY, Batten SR, Sakiyama H, Ma DY (2012) Inorg Chem Commun 19: 27-30.

Macrae CF, Edgington PR, McCabe P, Pidcock E, Shields GP, Taylor R, Towler M, Streek J (2006) J Appl Crystallogr 39: 453-457.

Nakamoto K (2009) Infrared and Raman Spectra of inorganic and coordination compounds Part A: Theory and applications in inorganic chemistry, John Wiley \& Sons, Inc., Hoboken, New Jersey.

Niu CY, Wu BL, Zheng XF, Zhang HY, Hou HW, Niu YY, Li ZJ (2008) Cryst Growth Des 8: 1566-1574.
Ondrejkovičová I, Galková S, Mroziński J, Kłak J, Lis T, Olejnik Z (2008) Inorg. Chim. Acta 361: 2483-2490.

Ondrejkovičová I, Wrzecion M, Nahorska M, Mroziński J (2009) Polish J Chem 83: 1547-1553.

Patil PC, Bhalerao DS, Dangate PS, Akamanchi KG (2009) Tetrahedron Letters 50: 5820-5822.

Ptaszyński B, Skiba E, Krystek J (1998) Thermochimica Acta 319(1-2): 75-85.

Richardson C, Steel PJ, D'Alessandro DM, Junk PC, Keene FR (2002) J Chem Soc Dalton Trans 13: 2775-2785.

Roubeau O, Gamez P, Teat SJ (2013) Eur J Inorg Chem 5-6: 934-942.

Semwal A, Chaudhary B, Singh R, Bagchi A (2013) Int J Pharm Tech Res 3: 1-13.

Sheldrick GM (2003) SADABS, Bruker AXS Inc., Madison, Wisconsin, USA.

Sheldrick GM (2015) Acta Cryst C71: 3-8.

Siddiqui N, Ahuja P, Ahsan W, Pandeya SN, Alam MS (2009) J Chem Pharm Res 1: 19-30.

Štefániková S, Ondrejkovičová I, Koman M, Lis T, Mroziński J, Wrzecion M (2008) J Coord Chem 61: 3895-3903.

Takikawa Y, Shimada K, Sato K, Sato, S. Takiyawa (1985) Bull Chem Soc Jpn 58: 995-999.

Uhrecký R, Ondrejkovičová I, Lacková D, Fáberová Z, Mroziński J, Kalińska B, Padělková Z, Koman M (2014) Inorg Chim Acta 414: 33-38.

Vei RJ, Li B, Huang RB, Zheng LS, Zheng Z (2011) Inorg Chem 50: 1170-1172.

Zhao XJ, Guo JH, Du M (2005) Acta Cryst E61: m913$\mathrm{m} 915$. 